\title{
EFFECT OF STREBLUS ASPER LEAVES ON LOCOMOTION, ANXIETY AND COGNITION IN RATS
}

\section{SACHIN NEEKHRA ${ }^{1}$, HIMANI AWASTHI ${ }^{2 *}$, DCP SINGH ${ }^{3}$}

${ }^{1}$ Department of Pharmacology, College of Pharmacy, SR Group of Institutions, Jhansi, Uttar Pradesh, India. ${ }^{2}$ Department of Pharmacology, Amity Institutes of Pharmacy, Amity University, Lucknow, Uttar Pradesh, India. ${ }^{3}$ Department of Pharmaceutical chemistry, HIMT College of Pharmacy, Greater Noida. Email: amitypharmacology123@gmail.com

Received: 3 August 2018, Revised and Accepted: 29 September 2018

ABSTRACT

Objective: The current study deals with the evaluation of neuropharmacological activities of hydroalcoholic extract of the plant Streblus asper

Methods: Hydroalcoholic extract of S. asper leaves was administered to animals at the dose of 200 and 400 mg/kg p.o., respectively. The neuropharmacological activities, namely, anxiolytic, muscle-relaxant, nootropic, and locomotor activities of hydroalcoholic extract of $S$. asper leaves were evaluated. The antioxidant activity of the hydroalcoholic extract of $S$. asper leaves was also investigated.

Results: The dose $400 \mathrm{mg} / \mathrm{kg}$ p.o. of hydroalcoholic extract indicated significant variation with control group on neuropharmacological activity, especially nootropic and locomotion, whereas the mentioned dose did not show a significant effect on anxiolytic and muscle-relaxant activities. Percentage scavenging activities and inhibition concentration ( $\mathrm{IC}_{50}$ ) were reported as 63.132 at $100 \mu \mathrm{g} / \mathrm{ml}$ and 35.33 , respectively.

Conclusion: It was found that hydroalcoholic extract of $S$. asper leaves can treat central nervous system disorders caused by oxidative stress.

Keywords: Neuropharmacological, Antioxidant, Streblus asper, Nootropic activity, Locomotion

(C) 2019 The Authors. Published by Innovare Academic Sciences Pvt Ltd. This is an open access article under the CC BY license (http://creativecommons. org/licenses/by/4. 0/) DOI: http://dx.doi.org/10.22159/ajpcr.2019.v12i2.28842

\section{INTRODUCTION}

In today's life of stress and strain, there is a direct need of agent having neuroprotective and neuropharmacological activity which can protect learning, memory, and behavior performance of the brain [1]. Stress involves complex immunological, neural, and biochemical mechanisms and plays a vital role in the genesis and progression of different kinds of diseased states [2]. Importantly, stress also affects cognitive functions leading to a delay in the progress of development and also affects the memory engram rather than the learning skill. Therapeutic use of psychoactive drugs was increasingly recognized as most effective in the treatment of stress, anxiety, and psychosomatic disorders during the past two decades, but these drugs have various adverse effects. Thus, herbal drugs primarily relieve the symptoms and give a palliative relief of a temporary nature.

Streblus asper is a gnarled tree known by several common names mostly Sihor, Siamese rough bush. It is geographically present in the drier portion of India, Malaysia, Thailand, and Sri Lanka [3]. S. asper contains myricetin, naringenin, kaempferol, quercetin, and ginkgetin flavonoids [4].

Flavonoids are a large group of plant secondary metabolites that share a basic phenyl benzopyrone feature and are found in all vascular plants where they occur in several structurally and biosynthetically related classes $[5,6]$. They are important components of the human dietary product. Among the variety of biological and pharmacological properties of these agents, we find a series of the literature review on their activity in the central nervous system (CNS) [7]. Some of the discovered flavonoid derivatives with a flavone-like structure such as quercetin and kaempferol have been therapeutically reported for neuropharmacological activity. S. asper possesses anticancer [8], anti-Parkinson [9], antidiabetic [10], anti-inflammatory [11], antifilarial [12], and anti-viral activities [13]. Therefore, we explored the effect of hydroalcoholic extract of $S$. asper leave on locomotion, anxiety, and cognition activity.

\section{METHODS}

\section{Animal}

All conditions were maintained according to the CPCSEA guideline. The animals of either sex were selected randomly from animal house having uniform weight of $160 \pm 20 \mathrm{~g}$. The room temperature was kept at $22 \pm 2{ }^{\circ} \mathrm{C}$ with free access to water and food. $1 \mathrm{~h}$ before the beginning of the experiment, animals were shifted to the laboratory and food and water were removed. The study protocol was approved by the institutional animal ethical committee (Approve Ref No. SRGI/COP/A/29/2016, CPCSEA Reg No. 1624/PO/a/CPCSEA)

\section{Plant material}

The leaves of $S$. asper collected from forest region of Lakhimpur Kheri district, Uttar Pradesh, India, were authenticated by taxonomist of CSIRNBRI, Lucknow, India. The voucher specimen of the plant was deposited in herbarium for future reference (NBRI/CIF/526/2016).

\section{Preparation of extraction}

The powdered drug ( $S$. asper) was taken and subjected to solvent extraction. The extraction of $S$. asper was carried out for $16 \mathrm{~h}$ with the hydroalcoholic solvent. A 1: $5 \mathrm{w} / \mathrm{v}$ ratio of drug and solvent was maintained.

The $S$. asper hydroalcoholic extract was concentrated by distilling the solvent and evaporated it until dry at low temperature, then weighed, and calculated the percentage of different extractive values.

\section{Phytochemical screening}

The hydroalcoholic extract of $S$. asper leaves was tested for various classes of chemical constituents by phytochemical tests for alkaloids, glycosides, flavonoids, phenolic compounds, saponins, and carbohydrates [14].

\section{Antioxidant activity}

Free radical scavenging activity (antioxidant activity) of $S$. asper hydroalcoholic extract was analyzed by 2,2-diphenyl-1-picrylhydrazyl 
(DPPH) assay. The stock solution $(20-100 \mu \mathrm{g} / \mathrm{mL})$ of $S$. asper hydroalcoholic extract was prepared in methanol. DPPH $(0.3 \mathrm{mM})$ reagent was added to the methanolic stock solutions of the sample $(20-100 \mu \mathrm{L})$ and kept in the dark at room temperature for $30 \mathrm{~min}$ [15]. The absorbance (A) of each sample extract was recorded at $517 \mathrm{~nm}$ using UV spectrophotometer (Shimadzu, Japan). A control sample was also prepared to approximate the radical scavenging followed by an equation:

Scavenging active $(\%)=\left(1-\frac{\text { Asample }}{\text { Acontrol }}\right) \times 100$

All tests were run in triplicates $(n=3)$, and the average values were calculated.

\section{IC $_{50}$ value}

DPPH method indicated inhibition concentration $\left(\mathrm{IC}_{50}\right)$ which calculated by the elucidation of the data results. The color reaction of the sample (absorbance) was plotted against the sample extract concentration to calculate $\mathrm{IC}_{50}$ value. It is defined as the volume of sample necessary to reduce the absorbance of DPPH by $50 \%$.

\section{Behavioral changes and toxicity studies ( $\left(\mathrm{LD}_{50}\right)$}

The doses (200 and $400 \mathrm{mg} / \mathrm{kg}$ ) of the hydroalcoholic extract of S. asper leaves were administered intraperitoneally to mice $(n=5)$ for 7 days, and behavioral changes were observed at 30-min interval up to $2 \mathrm{~h}$ on $7^{\text {th }}$ day after $1 \mathrm{~h}$ of drug administration [16].

For $\mathrm{LD}_{50}$ study, male mice $(\mathrm{n}=5)$ were received $S$. asper hydroalcoholic extract at $2000 \mathrm{mg} / \mathrm{kg}$ dose, and the mortality was recorded after $24 \mathrm{~h}$.

\section{Spontaneous locomotor activity}

The actophotometer is an instrument which measures locomotor activity by counting number of the steps of animal (movement of animals) by

Table 1: Phyto-chemical screening of hydro-alcoholic extract of Streblus nigra

\begin{tabular}{lll}
\hline S. No. & Class of compounds & $\begin{array}{l}\text { Hydroalcoholic extract } \\
\text { of Streblus asper }\end{array}$ \\
\hline 1 & Alkaloids & Present \\
2 & Glycoside & Present \\
3 & Flavonoids & Present \\
4 & Carbohydrates & Present \\
5 & Saponins & Present \\
6 & Phenolic compound & Present \\
\hline
\end{tabular}

cutting of a beam of light dropping on the photocell. In the actophotometer, rat was positioned individually for $10 \mathrm{~min}$ and basal activity score was recorded. Rat was divided into four groups $(\mathrm{n}=5)$. Group 1 received vehicle (DMSO), Groups 2 and 3 received S. asper hydroalcoholic extract (200 and $400 \mathrm{mg} / \mathrm{kg}$ ), and Group 4 received diazepam $2 \mathrm{mg} / \mathrm{kg}$ (standard drug group) for 7 consecutive days. Rat was positioned in the actophotometer for measuring the activity score after 60 min of treatment [17].

\section{Motor coordination}

The rats were skilled to sustain balance for 2 min on the revolving rod at the speed of $20 \mathrm{rpm}$. Only those rats which could balance themselves were qualified for the study. Each rat was positioned individually on the rotarod, and the total number of falls within 2 min was counted which was referred as the basal reading. Subsequently, the rats were separated into four groups each consisting of five animals. All the treatments of vehicle (dimethyl sulfoxide [DMSO]), S. asper hydroalcoholic extract (200 and $400 \mathrm{mg} / \mathrm{kg}$ ), and diazepam $(2 \mathrm{mg} / \mathrm{kg}$ ) were administered to rat for 7 consecutive days [18]. The rat was placed on Rota-Rod for recording the activity after $60 \mathrm{~min}$ of drug administration.

\section{Open-field test}

Open-field test is used to measure exploratory behavior range of anxiety-induced, locomotion activity. In this test, there was a novel and bright area. Rat was placed in the bright area that tends to stay away from brightly illuminated areas [19]. The wall was circular (33" diameter) with high dimension $(30 \mathrm{~cm})$ and composed of plywood. The black color was painted on the entire apparatus except for line $(6 \mathrm{~mm})$ that separated each floor. During the experiment, the place was kept in the dark except open-field apparatus. The doses of all treatment including vehicle (DMSO), S. asper hydroalcoholic extract (200 and $400 \mathrm{mg} / \mathrm{kg})$, and diazepam $(2 \mathrm{mg} / \mathrm{kg}$ ) were administered to rat for 7 consecutive days. Each rat was centrally positioned in the open-field apparatus for $5 \mathrm{~min}$ after $1 \mathrm{~h}$ of treatments, and the certain behavioral parameters were counted [20].

1. Ambulation: This was calculated by the number of spaces crossed by the animal.

2. Rearings: The number of times the animal stood on its hind limbs.

3. Immobility: Duration of time (s) the animal stayed immobile.

\section{Elevated plus maze (EPM)}

Anxiolytic activity (exploratory behavior) of rodents was evaluated by EPM model. In this model, two open arms $(50 \times 10 \mathrm{~cm})$ and two closed arms $(50 \times 10 \times 40 \mathrm{~cm})$ were positioned perpendicularly and elevated $50 \mathrm{~cm}$ above the floor. Group 1 served as control received vehicle (DMSO) and Groups 2, 3, and 4 served as S. asper hydroalcoholic extract

Table 2: Estimation of anti-oxidant activity of hydro-alcoholic extract of Streblus nigra using DPPH test

\begin{tabular}{llllll}
\hline S. No. & $\begin{array}{l}\text { Concentration of } \\
\text { hydroalcoholic extract }(\boldsymbol{\mu g} / \mathbf{m l})\end{array}$ & $\begin{array}{l}\text { Abs. of } \\
\text { extract }\end{array}$ & $\begin{array}{l}\text { Abs. of } \\
\text { control }\end{array}$ & $\begin{array}{l}\mathbf{S C V}(\%) \\
\text { extract }\end{array}$ & $\begin{array}{l}\mathbf{I C}_{\mathbf{5 0}}(\boldsymbol{\mu g} / \mathbf{m l}) \\
\text { Extract }\end{array}$ \\
\hline 1 & 20 & 0.342 & 0.632 & 45.88 & 35.33 \\
2 & 40 & 0.302 & 0.632 & 52.21 & \\
3 & 60 & 0.285 & 0.632 & 54.90 & \\
4 & 80 & 0.251 & 0.632 & 60.28 & \\
5 & 100 & 0.233 & 0.632 & 63.13 & \\
\hline
\end{tabular}

Values are mean \pm SEM $(n=5)$ One-way ANOVA followed by Dunnett's multiple comparison tests. *Significant variation as compared to vehicle control treated group $(\mathrm{p}<0.5) .{ }^{* *}$ Significant variation as compared to standard drug-treated group $(\mathrm{p}<0.05)$. SEM: Standard error of the mean. ANOVA: Analysis of varianace

Table 3: Effect of hydro- alcoholic extract of Streblus asper in locomotion test

\begin{tabular}{llllll}
\hline S. No. & Treatment & Dose & \multicolumn{2}{l}{ Number of steps (scores) in 10 min } \\
\cline { 4 - 6 } & & & $\begin{array}{l}\text { Before } \\
\text { treatment }\end{array}$ & $\begin{array}{l}\text { After } \\
\text { treatment }\end{array}$ & $\begin{array}{l}\text { Reduction in } \\
\text { activity (\%) }\end{array}$ \\
\hline 1 & & & $196.2 \pm 4.532$ & $132.2 \pm 2.596$ & $36.053 \pm 5.050$ \\
2 & Control & $200 \mathrm{mg} / \mathrm{kg} \mathrm{p.o.}$ & $121.8 \pm 3.56$ & $71.8 \pm 2.08$ & $40.83 \pm 2.4865$ \\
3 & Hydroalcoholic extract of Streblus asper & $400 \mathrm{mg} / \mathrm{kg} \mathrm{p} .0$. & $242.8 \pm 3.823$ & $135.6 \pm 5.25$ & $44.206 \pm 1.469$ \\
4 & Hydroalcoholic extract of Streblus asper & $2 \mathrm{mg} / \mathrm{kg}$ i.p. & $236.2 \pm 4.71$ & $113.2 \pm 3.435$ & $55.44 \pm 6.220^{*}$ \\
\hline
\end{tabular}


Table 4: Effect of hydro- alcoholic extract of Streblus asper in rota-rod test

\begin{tabular}{lllll}
\hline S. No. & Treatment & Dose & \multicolumn{2}{l}{ Number of falls in 2 min } \\
\cline { 3 - 4 } & & & $\begin{array}{l}\text { Basal } \\
\text { reading }\end{array}$ & \multicolumn{1}{c}{$\begin{array}{l}\text { After } \\
\text { reading }\end{array}$} \\
\hline 1 & & & $5.2 \pm 0.584$ & $5.6 \pm 0.511$ \\
2 & Control & $200 \mathrm{mg} / \mathrm{kg}$ p.o. & $6 \pm 0.708$ & $8 \pm 0.838$ \\
3 & Streblus asper hydroalcoholic extract & $400 \mathrm{mg} / \mathrm{kg}$ p.o. & $8.2 \pm 0.584$ & $9.2 \pm 0.582$ \\
4 & Streblus asper Hydroalcoholic extract & $2 \mathrm{mg} / \mathrm{kg}$ i.p. & $8.2 \pm 0.86$ & $12.2 \pm 0.801^{*}$ \\
\hline
\end{tabular}

Values are mean \pm SEM $(\mathrm{n}=5)$ One-way ANOVA followed by Dunnett's multiple comparison tests. *Significant variation as compared to vehicle control treated group $(\mathrm{p}<0.5)$. SEM: Standard error of the mean. ANOVA: Analysis of varianace

Table 5: Effect of hydro- alcoholic extract of Streblus asper in Open field test

\begin{tabular}{|c|c|c|c|c|c|}
\hline S. No. & Treatment & Dose & Ambulation & Immobilization & Rearing \\
\hline 1 & Control & & $71.2 \pm 2.381$ & $5.99 \pm 125.8$ & $4.8 \pm 0.862$ \\
\hline 2 & Streblus asper hydroalcoholic extract & 200 mg/kg p.o. & $88.2 \pm 1.719^{*}$ & $80.2 \pm 1.36$ & $8.2 \pm 0.736$ \\
\hline 3 & Streblus asper hydroalcoholic extract & 400 mg/kg p.o. & $93.6 \pm 4.213^{* *}$ & $69.6 \pm 0.929 * *$ & $9.8 \pm 0.66^{* *}$ \\
\hline 4 & Diazepam & 2.5 mg/kg i.p. & $104.6 \pm 5.368^{* *}$ & $61.4 \pm 1.507^{* *}$ & $11 \pm 1.227^{* *}$ \\
\hline
\end{tabular}

Values are mean \pm SEM $(n=5)$. One-way ANOVA followed by Dunnett's multiple comparison tests. *Significant variation as compared to vehicle control treated group $(\mathrm{p}<0.5) .{ }^{* *}$ Significant variation as compared to standard drug-treated group $(\mathrm{p}<0.05)$. SEM: Standard error of the mean. ANOVA: Analysis of varianace

Table 6: Effect of hydro-alcoholic extract of Streblus asper in Elevated plus maze test (anti-anxiety activity)

\begin{tabular}{|c|c|c|c|c|c|}
\hline S.No. & Treatment & Dose & $\begin{array}{l}\% \text { Preference } \\
\text { open arm }\end{array}$ & $\begin{array}{l}\text { Number of entries in } \\
\text { the open arm }\end{array}$ & $\begin{array}{l}\text { Time spent in } \\
\text { open arm (s) }\end{array}$ \\
\hline 1 & Control & & 28.59 & $3.4 \pm 0.511$ & $85.8 \pm 2.402$ \\
\hline 2 & Streblus asper hydroalcoholic extract & 200 mg/kg p.o. & 30.802 & $5.2 \pm 0.586$ & $92.4 \pm 4.97$ \\
\hline 3 & Streblus asper hydroalcoholic extract & $400 \mathrm{mg} / \mathrm{kg}$ p.o. & 33.01 & $4.6 \pm 0.245$ & $99 \pm 3.67$ \\
\hline 4 & Diazepam & $2 \mathrm{mg} / \mathrm{kg}$ i.p. & $52.9 *$ & $6.8 \pm 0.4912^{*}$ & $159 \pm 6.81^{*}$ \\
\hline
\end{tabular}

Values are mean \pm SEM ( $n=5$ ) One-way ANOVA followed by Dunnett's multiple comparison tests. *Significant variation as compared to vehicle control treated group $(\mathrm{p}<0.5)$. EPM: Elevated plus maze, SEM: Standard error of the mean. ANOVA: Analysis of varianace

Table 7: Effect of hydro-alcoholic extract of Streblus asper in Elevated plus maze test (nootropic activity)

\begin{tabular}{lllll}
\hline S. No. & Treatments & Dose & \multicolumn{2}{c}{ Transfer latency } \\
\cline { 3 - 5 } & & & Day 1 & Day $\mathbf{2}$ \\
\hline 1 & Control & & $43.4 \pm 2.881$ & $26.20 \pm 1.56$ \\
2 & Streblus asper hydroalcoholic extract & $200 \mathrm{mg} / \mathrm{kg} \mathrm{p.o.}$ & $33.6 \pm 1.21$ & $21.20 \pm 1.24^{*}$ \\
3 & Streblus asper hydroalcoholic extract & $400 \mathrm{mg} / \mathrm{kg} \mathrm{p.o.}$ & $25.2 \pm 1.63$ & $17.80 \pm 1.11^{* *}$ \\
4 & Paracetamol & $100 \mathrm{mg} / \mathrm{kg}$ i.p. & $21.2 \pm 0.971$ & $15.40 \pm 1.07^{* *}$ \\
\hline
\end{tabular}

Values are mean \pm SEM $(n=5)$ One-way ANOVA followed by Dunnett's multiple comparison tests. *Significant variation as compared to vehicle control treated group $(\mathrm{p}<0.5) .{ }^{* *}$ Significant variation as compared to standard drug-treated group $(\mathrm{p}<0.05)$. SEM: Standard error of the mean. ANOVA: Analysis of varianace, EPM: Elevated plus maze

(200 and $400 \mathrm{mg} / \mathrm{kg}$ ) and the standard group received diazepam ( $2 \mathrm{mg} / \mathrm{kg}$ ), respectively, for 7 consecutive days. On the $7^{\text {th }}$ day, the rats were individually positioned on the center of the maze after $1 \mathrm{~h}$ of oral administration. During 5 min of the observation period, we noted the time spent in opened arms and the number of entries [21].

\section{EPM}

Recently, EPM model is utilized for the evaluation of nootropic activity [22] (learning and acquisition of memory). The EPM consisting of two open arms $(50 \times 10 \mathrm{~cm})$ and two covered arms $(50 \times 10 \times 40 \mathrm{~cm})$ were positioned perpendicularly and elevated $50 \mathrm{~cm}$ above the floor. Each rat was placed at the terminal site of an open arm facing away from the central platform on the $1^{\text {st }}$ day. The rat was moved from the open arm into closed arms which counted as time domain (second) called as transfer latency (TL). The vehicle (DMSO) and treated drug were administered for 7 consecutive days. On the $1^{\text {st }}$ day, TL was noted for each animal after $1 \mathrm{~h}$ of oral administration. If the animal could not reach one of the covered arms within $90 \mathrm{~s}$, it was mildly pushed into one of the two closed arms and TL considered as $90 \mathrm{~s}$. For another $2 \mathrm{~min}$, the rat was allowed to stand on the maze. Then, rat was shifted to its home cages. It was again noted TL on 2 and 7 days which animal exhibit for this learned-task (acquisition of memory) after the $1^{\text {st }}$ time trial [23].

\section{Body temperature}

Body temperature was noted after or prior administering of control vehicle, test, and standard treatment dose. It was recorded by inserting about $2 \mathrm{~cm}$ into the rectum of the animals which enabled with a thermoelectric probe linked to digital thermometer.

\section{Statistical analysis}

The results are representing as a mean \pm SEM. The statistical significance was analyzed using one-way analysis of variance followed by Dunnett's test. Significant of $\mathrm{P}$ value was to be considered when the difference of $P$ value was less than 0.05 .

\section{RESULTS AND DISCUSSION}

Acute toxicity and general behavior studies-

$S$. asper hydroalcoholic extract $(2000 \mathrm{mg} / \mathrm{kg}$ ) wasadministered to mice for conduction of acute toxicity studies $\left(\mathrm{LD}_{50}\right)$. During conducting $\mathrm{LD}_{50}$, it was regularly observed for any general behavioral changes. It was resulted that The significant reductions in drowsiness, spontaneous locomotor motility were observed. 
Hydroalcoholic extract of $S$. asper leaves results as changing the general behavior patterns and reducing normal body temperature. All of the two results concluded that a CNS-depressant action of hydroalcoholic extract was validated by this model.

The results obtained demonstrated that hydroalcoholic extract at a dose of 200 and $400 \mathrm{mg} / \mathrm{kg}$, respectively, indicated that increase in the TL showed significant improvement in the acquisition and retention of memory of the learned task, thus resulting in nootropic activity.

It is probable that the building of memory was amplified on the involvement of neurotransmitters when the repeated administration of the drug was achieved. There was prediction that the serotonergic, noradrenaline, and central cholinergic transmission play an important role in the cognitive function of the brain $[24,25]$.

In our study, the hydroalcoholic extract of $S$. asper leaves did not produce any significant change in the anxiolytic activity using the EPM model. Anxiolytic compounds, by decreasing anxiety, increased the open arm exposing time as well as the number of entries into the open arm. The hydroalcoholic extract of the plant failed to demonstrate any such effect in the rats, and hence, we can conclude that extract does not possess anxiolytic activity. In generaL, most of the anxiolytic agents have an adverse effect on memory as seen with the benzodiazepines, commonly used as anxiolytics [26]. In the current situation, EPM model is also being used to analyze learning and acquisition of memory in rodents. Scopolamine, an anticholinergic agent inducing the impairment of learning and memory, is revealed by extended transfer of latency from the open arm to the closed arm [27]. With respect to our results, in contrast to that of diazepam, hydroalcoholic extract did not cause any improvement in the number of entries into the open arm.

Locomotor activity is reflected as an index of alertness and a decline in it would observe sedative activity. The hydroalcoholic extract showed results which had no influence on the locomotor activity (index of alertness and a decline in it would observe sedative activity). Therefore, the insignificance of effect on locomotor activity was indicated which referred to the advantage of the plant indicating nootropic activity.

It was observed that hydroalcoholic extract possess neurobiological activity. It was reflected by the presence of flavonoids.

\section{CONCLUSION}

It was concluded that $S$. asper hydroalcoholic extract exhibits a potential role in memory enhancing but haS no effect on locomotion, motor coordination, and anxiolytics activity.

\section{ACKNOWLEDGMENT}

The authors are gratefully for Director, College of Pharmacy, SR Group of institutions, Jhansi, and also thank National Botanical Research Institute, Lucknow for providing plant sample (S. asper).

\section{CONFLICTS OF INTEREST}

All authors have none to declare.

\section{AUTHORS' CONTRIBUTIONS}

Himani awasthi and DCP singh contributed equally to this work.

\section{REFERENCES}

1. Mukherjee P, Roy U. Neuropharmacological profile of an herbal medicine formulation 'Trasina' with special reference to antistress activity. Indian J Med Res 1990;84:227-2.

2. Sen P, Mediratta PK, Ray A. Effects of Azadirachta indica A Juss on some biochemical, immunological and visceral parameters in normal and stressed rats. Indian J Exp Biol 1992;30:1170-5.

3. Basuri TS. Analgesic activity of stem bark extracts of Sterblus asper. Int J Pharm Pharm Sci 2011;3:219-20.

4. Li C, Huang C, Lu T, Wu L, Deng S, Yang R, Li J. Tandem mass spectrometric fragmentation behavior of lignans, flavonoids and triterpenoids in Streblus asper. Rapid Commun Mass Sp 2014; 28:2363-70

5. Harborne JB, Williams CA. Advances in flavonoid research since 1992. Phytochemistry 2000;55:481-504.

6. Paladini AC, Marder M, Viola H, Wolfman C, Wasowski C, Medina JH. Flavonoids and the central nervous system: From forgotten factors to potent anxiolytic compounds. J Pharm Pharm 1999;51:519-6.

7. Hernandez EA, Eva-gonzalez M, Anna LM, Moreno J, Kite G, Terrazas T, et al. HPLC/MS analysis and anxiolytic-like effect of quercetin and kaempferol flavonoids from Tilia americana var. Mexicana. J Ethnopharm 2010;217:91-7.

8. Alamgir AN, Rahman M, Rahman A. Phytochemical characteristics, antimitotic, cytotoxic and antitumor activities of bark extract of Streblus asper lour. Bangladesh J Bot 2013;42:17-2.

9. Singsai K, Akaravichien T, Kukongviriyapan V, Jintana S. Protective effects of Streblus asper leaf extract on $\mathrm{H}_{2} \mathrm{O}_{2}$-induced ROS in SK-N$\mathrm{SH}$ cells and MPTP-induced parkinson's disease-like symptoms in C57BL/6 mouse. Evid Based Complementary Altern Med 2015;1:1-6.

10. Karan SK, Mondal A, Mishra SK, Pal DK, Rout KK. Anti-diabetic effect of Streblus asper in streptozotocin-induced diabetic rats. Pharm Biol 2013;51:369-5

11. Sripanidkulchai B, Junlatat J, Wara NA, Hormdee D. Anti-inflammatory effect of Streblus asper leaf extract in rats and its modulation on inflammation-associated genes expression in RAW264.7 macrophage cells. J Ethnopharm 2009;124:566-70.

12. Nazneen P, Singhal KC, Khan NU, Singhal P. Potential antifilarial activity of Streblus asper against Setaria cervi (Nematoda: Filarioidea). Indian J Pharm 1989;21:16-21.

13. Hong C, Li J, Wu Q, Niu XT, Tang MT, Guan XL, et al. Anti-HBV activities of Streblus asper and constituents of its roots. Fitoterapia 2012;83:643-9.

14. Vishnoi NK. Advanced Practical Organic Chemistry. $2^{\text {nd }}$ ed. New Delhi: Vikas Publishing House; 2007.

15. Raghbir CG, Sharma V, Sharma N, Kumar N, Singh B. In vitro antioxidant activity from leaves of Oroxylum indicum (L.) Vent. - A North Indian highly threatened and vulnerable medicinal plant. J Pharm Res 2008;1:65-72.

16. Irwin S. Drug screening and evaluative procedures. Science 1962;136 Suppl 3511:123-8.

17. Rani IV, Kiranmai G, Pulla RP. Pharmacological evaluation of antianxiety activity of Desmostachya bipinnata leaves in animal models. Int J Curr Pharm Res 2017;9:152-4.

18. Kulkarni SK, Joseph P. Psychopharmacological profile of siotone granules, a herbal preparation. Indian Drugs 1997;35:536-45.

19. Fancy FA, Shahriar M, Islam MD, Bhuiyan MA. In-vivo anti-pyretic, anti-nociceptive, neuropharmacological activities and acute toxicity investigations of Blumea lacera. Int J Pharm Pharm Sci 2015;7:472-7.

20. Sharma DNK, Khosa RL, Chansauria JP, Sahai M. Antistress activity of Tinospora cordfolia and Centella asiutica extracts. Phytother Res 1996;10:181-3.

21. Cheng WW, LinCT, ChuFH, Chang ST, Wang SY. Neuropharmacological activities of phytoncide released from Cryptomeria japonica. J Wood Sci 2009;55:27-31.

22. Dhingra D, Parle M, Kulkarni SK. Memory enhancing activity of Glycyrrhiza glabra in mice. J Ethnopharm 2004;91:361-5.

23. Itoh J, Nabeshima $T$, and Kameyama T. Utility of an elevated plusmaze for the evaluation of memory in mice: Effects of nootropics, scopolamine and electro-convulsive shock. Psychopharmacology 1990;101 Suppl 1:27-33.

24. Hollander E, Mohs RC, Davis KS. Cholinergic approaches to the treatment of Alzheimer's disease. Br Med Bull 1986;42:97-100.

25. Ogren SO. Biology of Serotonergic Transmission. Chichester: John Wiley and Sons; 1982. p. 317-34

26. Mrugnandam AV, Kumar V, Bhattacharya SK. Status report on neuropharmacology. Indian J Pharm 2000;32:119-33.

27. Iyer MR, Pal SC, Kasture VS, Kasture SB. Effect of Lawsonia inermis on memory and behavior mediated via monoamine neurotransmitters. Indian J Pharm 1998;30:181-5. 